\title{
A REPORT UPON EIGHT HUNDRED CONSECUTIVE ADMINISTRATIONS OF CHLOROFORM TO CANINE PATIENTS.
}

\author{
By Frederick Hobday, F.R.C.V.S., Royal Veterinary \\ College, London.
}

SOME little time ago ${ }^{1}$ there were published notes upon 500 consecutive chloroformisations of canine patients by the aid of a certain pattern of inhaler and a rational method of administration. Out of these only one death occurred, and two other patients exhibited symptoms of danger but recovered. The main object of the observations was to do away, at all events in the minds of the members of the veterinary profession, with the prevalent idea that the dog could not be chloroformed with any reasonable degree of safety. This idea was persistently taught in the colleges even as recently as 1895, and, although I do not think that the present-day graduates will hesitate to administer this agent before performing any painful operation where a general anæsthetic is needed, old ideas die hard. It is in order that the more general use of chloroform may be furthered that the following records have been kept.

\begin{tabular}{|c|c|c|c|c|c|c|c|c|}
\hline Date. & No. & Breed. & Sex. & Age. & Condition. & Operation. & $\begin{array}{c}\text { Time taken } \\
\text { to Anes- } \\
\text { thetise. }\end{array}$ & $\begin{array}{c}\text { Period of } \\
\text { Complete } \\
\text { Ancesthesia. }\end{array}$ \\
\hline 1898 & & & & & & & & \\
\hline June 1 & 501 & St. Bernard & $\mathrm{M}$ & $3 \mathrm{mos}$ & Good & Reduce fracture & 4 mins. & 7 mins. \\
\hline & 502 & Retriever & $M$ & $15 \mathrm{mos}$. & Good & $\overline{-5}$ & $4 \frac{1}{2}$ mins. & 8 mins. \\
\hline July 14 & 503 & $\begin{array}{l}\text { Fox terrier } \\
\text { Pug }\end{array}$ & F & $\begin{array}{l}\text { Aged } \\
4 \text { vrs }\end{array}$ & $\begin{array}{c}\text { Good } \\
\text { Fat }\end{array}$ & $\begin{array}{l}\text { Remove tumour } \\
\text { Oophorectomy }\end{array}$ & $\begin{array}{l}5 \text { mins. } \\
21 \text { mins. }\end{array}$ & $\begin{array}{l}20 \text { mins. } \\
26 \text { mins. }\end{array}$ \\
\hline$" 15$ & 505 & Wire-haired terrier & $\mathrm{F}$ & $5 \mathrm{yrs}$. & Six weeks & Ovaro-hysterectomy & 2 mins. & 28 mins. \\
\hline Sept. 4 & 506 & Manchester toy & $\mathrm{F}$ & 3 yrs. & Pregnant & Parturition & $1 \mathrm{~min}$. & 50 mins. \\
\hline & 507 & Pug mongrel & M & 10 mos. & Good & 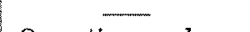 & $4 \frac{1}{2}$ mins. & $11 \mathrm{~m}$ \\
\hline & 508 & Bull terrier & M & 3 mos. & Good & Operation on claws & $1 \mathrm{~min}$. & 22 mins. \\
\hline $\begin{array}{l}8 \\
8\end{array}$ & $\begin{array}{l}509 \\
510\end{array}$ & $\begin{array}{l}\text { Fox terrier } \\
\text { Collie }\end{array}$ & $\stackrel{\mathrm{M}}{\mathrm{F}}$ & $\begin{array}{l}2 \mathrm{yrs} \\
3 \mathrm{mos} .\end{array}$ & $\begin{array}{l}\text { Good } \\
\text { Good }\end{array}$ & Amputation of leg & $\begin{array}{l}2 \text { mins, } \\
2 \text { mins. }\end{array}$ & \\
\hline, & 511 & Italian greyhound & $\mathrm{M}$ & 12 mos. & Poor & Chorea & 4 mins. & 20 mins. \\
\hline 9 & 512 & Airedale & $\mathbf{M}$ & 10 mos. & Good & Amputation of digits & & 20 mins. \\
\hline $\begin{array}{r}9 \\
10\end{array}$ & 513 & Toy & $\mathbf{F}$ & 5 yrs. & Good & Remove tumour & 2 mins. & nins. \\
\hline $\begin{array}{l}10 \\
10\end{array}$ & 514 & & M & 2 yrs. & & Col & 3 mins. & 30 mins. \\
\hline $\begin{array}{l}10 \\
19\end{array}$ & 515 & Toy & $\mathbf{F}$ & $7 \mathrm{mos}$. & Good & Amputation of leg & 1/2 mins. & 25 mins. \\
\hline 19 & $\begin{array}{l}310 \\
517\end{array}$ & $\begin{array}{l}\text { Fox terrier } \\
\text { Fox terrier }\end{array}$ & $\underset{\mathrm{F}}{\mathrm{M}}$ & Aged & $\begin{array}{l}\text { Very tat } \\
\text { Weak }\end{array}$ & $\begin{array}{c}\text { Hrematoma of ear } \\
\text { Hysterectomy }\end{array}$ & ns. & 14 mins. \\
\hline 22 & 518 & Manchester terrier & $\mathbf{F}$ & 9 yrs. & Fat & & & 9 mins. \\
\hline 22 & 519 & Blenheim spaniel & $\mathbf{F}$ & 6 yrs. & $\begin{array}{l}\text { Pregnant, } \\
\text { fat }\end{array}$ & Cæesarean section & 2 mins. & $1 \mathrm{hr} .4 \mathrm{mins}$. \\
\hline 26 & 520 & Manchester terrier & M & $8 \mathrm{mos}$. & Good & 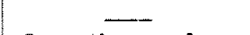 & $2 \frac{1}{2}$ mins. & $13 \mathrm{~min}$ \\
\hline 27 & 521 & Whip & M & $10 \mathrm{mos}$ & & Operation on claws & $3 \mathrm{mi}$ & 29 mins. \\
\hline $\begin{array}{l}28 \\
29\end{array}$ & 522 & Setter & $\mathbf{F}$ & Aged & Good & Remove tumour & 10 mins. & 28 mins. \\
\hline Oet. $\quad 8$ & 523 & $\begin{array}{l}\text { Collie } \\
\text { Black and tan terrier }\end{array}$ & MI & 10 mos. & Poor & Fracture \& resot limb & 8 mins. & 8 mins. \\
\hline 8 & 525 & $\begin{array}{l}\text { Black and tan terrier } \\
\text { Fox terrier }\end{array}$ & $\mathbf{M}$ & $12 \mathrm{mos}$. & Very fat & Remove tumour & $4 n$ & 20 mins. \\
\hline 10 & 526 & Tonate & M & - & Good & & & 12 mins. \\
\hline 13 & 527 & Dalmatian & $\mathbf{M}$ & 2 yrs. & Poor & Laparotomy & 3 mins. & 16 mins. \\
\hline
\end{tabular}

1 "Journal of Comparative Pathology and Therapeutics," Vol. VIII., p. 287 ; Vol. XI., p. 114.

"Veterinary Record," Vol. X., p. 163. 


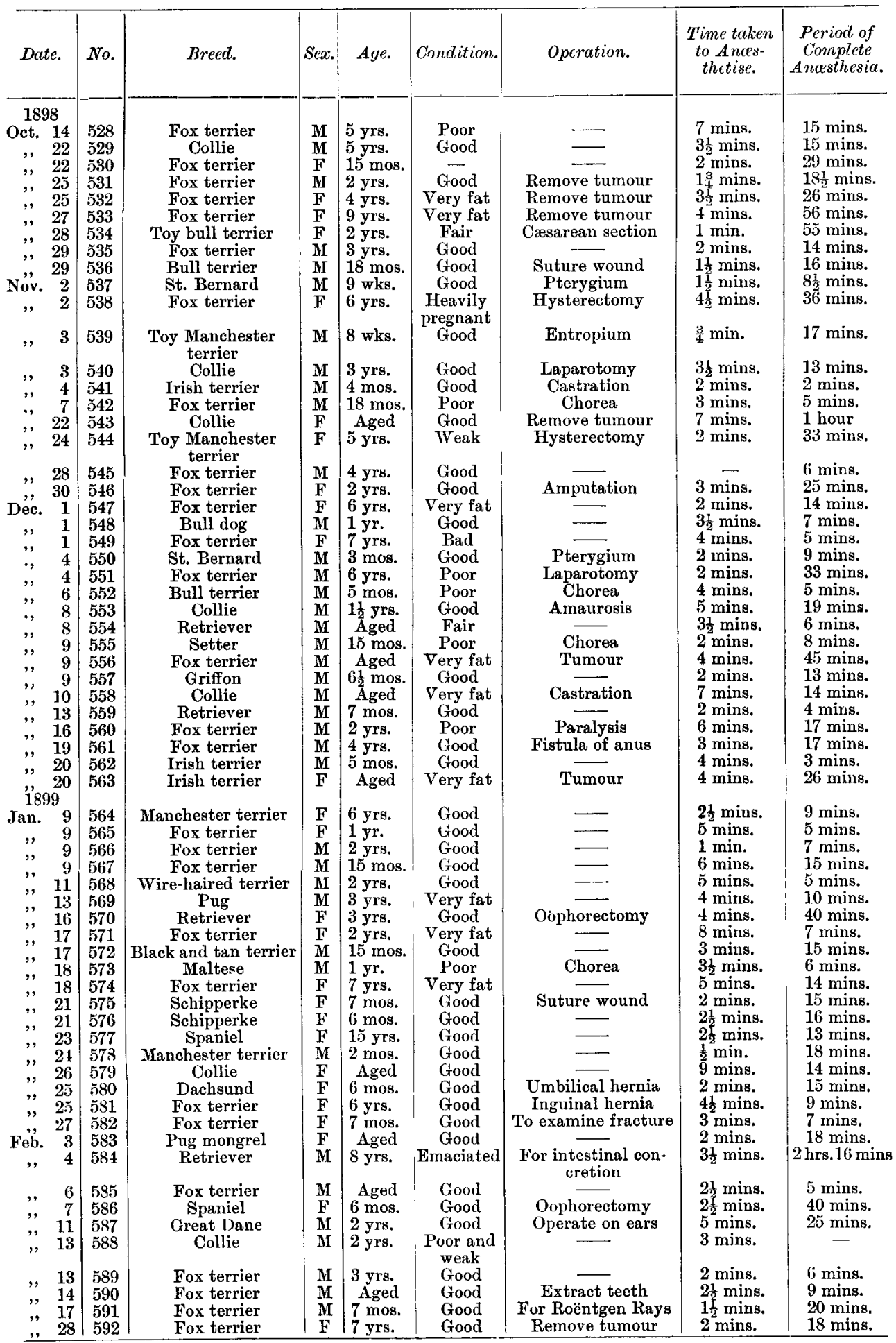




\begin{tabular}{|c|c|c|c|c|c|c|c|c|}
\hline Date. & No. & Breed. & Sex. & Aye. & Condition. & Operution. & $\begin{array}{l}\text { Time taken } \\
\text { to Anas- } \\
\text { thetise. }\end{array}$ & $\begin{array}{c}\text { Period of } \\
\text { Complete } \\
\text { Ancesthesia. }\end{array}$ \\
\hline $\begin{array}{l}1899 \\
\text { Feb. } 28\end{array}$ & 593 & Fox terrier & F & Aged & Good & Remove tumour & $2 \frac{1}{2}$ mins. & \\
\hline $\operatorname{March} 6$ & 594 & Blenheim spaniel & $\mathbf{F}$ & 4 yrs. & Good & Dystokia & 3 mins. & 30 mins. \\
\hline,,$\quad 6$ & 595 & Terrier & $\mathrm{MI}$ & $10 \frac{1}{2}$ yrs. & $\begin{array}{l}\text { Fat, } \\
\text { asthma }\end{array}$ & & 3 mins. & 6 mins. \\
\hline, 7 & 596 & Retriever & MI & Aged & Good & & 9 mins. & 4 mins. \\
\hline 8 & 597 & Irish terrier & $\mathrm{F}$ & $6 \mathrm{mos}$. & Poor & Oophorectomy & $3 \frac{1}{2}$ mins. & 2 mins. \\
\hline ", 12 & 598 & Fox terrier & $\mathbf{F}$ & 3 yrs. & Good & Inguinal hernia & 3 mins. & $1 \mathrm{hr} .10 \mathrm{mins}$ \\
\hline , 15 & 599 & Fox terrier & $\mathbf{F}$ & 7 yrs. & Good & Inguinal hernia & $2 \frac{1}{2}$ mins. & \\
\hline $\begin{array}{ll}20 \\
, & 21\end{array}$ & $\begin{array}{l}600 \\
601\end{array}$ & $\begin{array}{l}\text { Irish terrier } \\
\text { Fox terrier }\end{array}$ & $\underline{F}$ & -- & $\begin{array}{l}\text { Good } \\
\text { Good }\end{array}$ & Removal of tumour & 5 mins. & 45 mins. \\
\hline, 21 & 602 & Fox terrier & $\mathrm{F}$ & $5 \mathrm{yrs}$. & Good & $\begin{array}{l}\text { Keduce iracture } \\
\text { Remove tumour }\end{array}$ & $\begin{array}{l}5 \text { mins. } \\
6 \text { mins. }\end{array}$ & $\begin{array}{l}9 \text { mins. } \\
40 \text { mins. }\end{array}$ \\
\hline , 21 & 603 & Pug & $\mathbf{F}$ & Aged & Very fat & & $1 \frac{1}{2}$ mins. & 13 mins. \\
\hline & 604 & Fox terrier & $\mathrm{M}$ & 12 mos. & Good & & $2 \frac{1}{2}$ mins. & 10 mins. \\
\hline April 4 & 605 & Whippet & $\mathbf{M}$ & 6 mos. & Good & Dislocated shoulder & 4 mins. & 6 mins. \\
\hline ,", & $\begin{array}{l}606 \\
607\end{array}$ & $\begin{array}{c}\text { Fox terrier } \\
\text { Yorkshire terrier }\end{array}$ & $\begin{array}{l}\mathbf{F} \\
\mathbf{M}\end{array}$ & $\begin{array}{l}3 \text { yrs. } \\
6 \text { yrs. }\end{array}$ & $\begin{array}{l}\text { Good } \\
\text { Good }\end{array}$ & Lithotomy & $\begin{array}{l}2 \frac{1}{2} \text { mins. } \\
4 \text { mins. }\end{array}$ & 7 mins. \\
\hline $\begin{array}{ll}, & 6 \\
, & 6\end{array}$ & $\begin{array}{l}008 \\
608\end{array}$ & Welsh terrier & $\mathbf{F}$ & 4 yrs. & Good & & $\begin{array}{l}4 \text { mins. } \\
3 \text { mins. }\end{array}$ & $\begin{array}{l}35 \text { mins. } \\
5 \text { mins. }\end{array}$ \\
\hline$", \quad 5$ & 609 & Retriever & M & 3 yrs. & Weak & Laparo-enterotomy & 4 mins. & $\ddot{1}$ hour \\
\hline 10 & 610 & Fox terrier & $\mathbf{F}$ & 7 mos. & Weak & Laparo-gastrotomy & & ins. \\
\hline 13 & 611 & Irish terrier & $\mathbf{F}$ & 18 mos. & Good & Ōophorectomy & 4 mins. & 47 mins. \\
\hline 15 & 612 & Dal & M & 3 yrs. & Good & $\overline{-}$ & 3 mins. & 10 mins. \\
\hline 19 & 613 & Prince Charles & M & Aged & Weak & Lit] & 4 mins. & nins. \\
\hline , 25 & 614 & $\begin{array}{l}\text { Toy Pomeranian } \\
\text { Wire-haired terrier }\end{array}$ & $\mathbf{F}$ & $12 \mathrm{yrs}$. & Good & Remov & $2 \frac{1}{2}$ mins. & 9 mins. \\
\hline $\begin{array}{ll}, & 19 \\
, & 28\end{array}$ & $\begin{array}{l}615 \\
616\end{array}$ & $\begin{array}{l}\text { Wire-haired terrier } \\
\text { Wire-haired terrier }\end{array}$ & $\mathbf{M}$ & 3 yrs. & Good & Laparotomy & 4 mins. & 17 mins. \\
\hline May 3 & 617 & Fox terrier & MI & $\begin{array}{l}4 \text { yrs. } \\
10 \text { mos. }\end{array}$ & $\begin{array}{l}\text { Good } \\
\text { Good }\end{array}$ & $\begin{array}{c}\text { Suture gastrocnemius } \\
\text { tendon }\end{array}$ & $\begin{array}{l}3 \frac{1}{2} \text { mins. } \\
2 \text { mins. }\end{array}$ & $\begin{array}{l}4 \text { mins. } \\
30 \text { mins. }\end{array}$ \\
\hline ," & 618 & Toy Manchester & $\mathbf{F}$ & 9 yrs. & Good & Inguinal hernia & $1 \mathrm{~min}$. & 32 mins. \\
\hline $\begin{array}{ll}, & 6 \\
0\end{array}$ & 619 & Great Dane & MI & 3 yrs. & Good & Ampu & & \\
\hline " 9 & 620 & Fox ter & $\mathbf{F}$ & $5 \mathrm{yrs}$. & Fat & Mammary tumour & $2 \frac{1}{4}$ mins. & 19 mins. \\
\hline "10 & 621 & $\begin{array}{l}\text { Retriever } \\
\text { Dachsund }\end{array}$ & $\mathbf{F}$ & $\overline{0}$ & $\overline{\mathrm{P} p \mathrm{x}}$ & $y$ tumour & 2 mins. & 12 mins. \\
\hline $\begin{array}{ll}" 10 \\
" 18\end{array}$ & $\begin{array}{l}622 \\
623\end{array}$ & $\begin{array}{l}\text { Dachsund } \\
\text { Fox terrier }\end{array}$ & $\mathbf{F}$ & $\begin{array}{l}\text { o yrs. } \\
12 \text { yrs. }\end{array}$ & $\begin{array}{l}\text { Poor } \\
\text { Good }\end{array}$ & 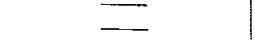 & $\operatorname{mins}$ & 6 mins. \\
\hline ", 23 & 624 & Retriever & M & 10 yrs. & Good & Laparotomy & $\begin{array}{l}1 \frac{1}{2} \text { mins. } \\
5 \text { mins. }\end{array}$ & $\begin{array}{l}0 \text { mins. } \\
55 \text { mins. }\end{array}$ \\
\hline ", 25 & 625 & Fox terrier & $\mathbf{F}$ & 6 yrs. & Fat & $\begin{array}{c}\text { Reduce inguinal } \\
\text { hernia }\end{array}$ & 4 mins. & 40 mins. \\
\hline 26 & 626 & Collie & M & Aged & Good & Amputation of toe & 4 mins. & $18 \mathrm{~min}$ \\
\hline 29 & 627 & Spaniel & $\mathbf{M I}$ & Aged & Good & & & \\
\hline$\Rightarrow 30$ & 628 & Great Dane & $\bar{\pi}$ & - & Good & Amputate tail & 12 mins. & 20 mins. \\
\hline June 2 & 629 & $\begin{array}{l}\text { Retriever } \\
\text { Collie }\end{array}$ & $M$ & Aged & Good & Laparo-enterotomy & 2 mins. & 53 mins. \\
\hline $\begin{array}{ll}2 \\
י & 3\end{array}$ & $\begin{array}{l}630 \\
631\end{array}$ & $\begin{array}{l}\text { Collie } \\
\text { Toy Bull }\end{array}$ & $\underset{F}{M}$ & $2 \longdiv { \mathrm { vrs } }$ & Good & Ampu & 5 mins. & 49 mins. \\
\hline$"$ & 632 & $\begin{array}{l}\text { Toy Bull } \\
\text { Maltese terrier }\end{array}$ & $\stackrel{F}{F}$ & $\begin{array}{l}2 \text { yrs. } \\
5 \text { yrs. }\end{array}$ & $\begin{array}{l}\text { Weak } \\
\text { Good }\end{array}$ & terectomy & $2 \frac{1}{2}$ mins. & 30 mins. \\
\hline ", & 633 & Spaniel & $\mathrm{F}$ & Aged & Good & Mamma & $\begin{array}{l}2 \text { mins. } \\
5 \text { miıs. }\end{array}$ & 12 mins. \\
\hline , & 634 & Toy $\mathrm{Y}_{0}$ & $\mathrm{~F}$ & 3 yrs. & Good & Inguinal hernia & & $\begin{array}{l}34 \text { mins. } \\
24 \text { mins. }\end{array}$ \\
\hline ", & 635 & Fox terrier & $\mathbf{F}$ & 4 yrs. & Very fat & Mammary tumour & $4 \mathrm{mir}$ & 29 mins. \\
\hline & 636 & & $\mathrm{~F}$ & 10 yrs. & Very fat & & $6 n$ & 5 mins. \\
\hline $\begin{array}{l}8 \\
, \quad 26\end{array}$ & 637 & Collie & M & - & Poor & & & 6 mins. \\
\hline$\Rightarrow \quad 26$ & $\begin{array}{l}638 \\
639\end{array}$ & $\begin{array}{c}\text { Fox terrier } \\
\text { Aberdeen terrier }\end{array}$ & $\mathrm{F}$ & 4 yrs. & Poor & $\mathrm{Ca}$ & 3 mins. & \\
\hline,$\quad 27$ & 640 & Bull & $\mathrm{MI}$ & $12 \mathrm{yrs}$. & $\begin{array}{l}\text { Good } \\
\text { Good }\end{array}$ & Extract teeth & 2 mins. & 2 mins. \\
\hline , 28 & 641 & Toy Manchester & $\mathbf{F}$ & 9 yrs. & Fat & & $\begin{array}{l}{ }_{2} \overline{2} \text { mins. } \\
2 \text { mins. }\end{array}$ & $\begin{array}{l}6 \text { mins. } \\
14 \text { mins. }\end{array}$ \\
\hline 28 & 642 & Toy Mar & $\mathbf{F}$ & 6 yrs. & Good & Inguinal hernia & & 15 mins. \\
\hline 29 & 643 & & M & Aged & & & & 5 mins. \\
\hline 30 & 644 & Fox & $\mathbf{F}$ & 3 yrs. & Good & & $2 \frac{1}{2}$ mins. & 6 mins. \\
\hline Tuly 1 & 645 & Pomeranian & M & 9 yrs. & Good & Amaurosis & $1 \frac{1}{2}$ mins. & 13 mins. \\
\hline , & 646 & Mongrel Airedale & $\mathbf{M}$ & 4 yrs. & Good & Amputate ear flap & 4 mins. & 5 mins. \\
\hline , & 647 & $\begin{array}{l}\text { Toy Manchester } \\
\text { Irish terrier }\end{array}$ & $\mathbf{F}$ & $6 \mathrm{yrs}$. & Good & Inguinal hernia & $3 \frac{1}{2}$ mins. & 21 mins. \\
\hline$"$ & $\begin{array}{l}648 \\
649\end{array}$ & $\begin{array}{l}\text { Iris } \\
\text { Fo }\end{array}$ & $\begin{array}{l}\mathbf{M} \\
\mathbf{M}\end{array}$ & 7 mos. & $\begin{array}{l}\text { Poor } \\
\text { Good }\end{array}$ & Cho & 2 mins. & 5 mins. \\
\hline 13 & 650 & $\begin{array}{l}\text { Fox terrier } \\
\text { Fox terrier }\end{array}$ & M & 7 yrs. & $\begin{array}{c}\text { Good } \\
\text { Fat }\end{array}$ & Laparotomy & ns. & 12 mins. \\
\hline 14 & 651 & Collio & M & 8 yrs. & Poor & & 2 mins. & 3 mins. \\
\hline 16 & 652 & Schipperke & II & $1 \mathrm{yr}$. & Good & Fistula in neck & $1 \frac{1}{2}$ mins. & 29 mins. \\
\hline 17 & 653 & Pomeranian & $\mathbf{M}$ & $5 \mathrm{yrs}$. & Good & 一 & & 8 mins. \\
\hline 17 & 654 & Fox terrier & $\mathbf{F}$ & - & Good & & $1 \frac{1}{2}$ mins. & 12 mins. \\
\hline 17 & $65 \overline{5}$ & Fox terrier & MI & Aged & Good & Iithotorny & $2 \frac{1}{2}$ mins. & 9 mins. \\
\hline 22 & 656 & Fox terrier & $\mathrm{F}$ & 15 mos. & Good & Ovaro-hysterectomy & 4 mins. & $17 \frac{1}{2}$ mins. \\
\hline 24 & 657 & Spaniel & $\mathrm{F}$ & 12 yrs. & Goorl & Remove tumour & 3 mins. & 17 mins. \\
\hline 24 & 658 & Mongrel & $\mathbf{F}$ & - & Good & Tumour & & \\
\hline 24 & 659 & Terrier & $\mathbf{M}$ & 10 mos. & Good & $\begin{array}{l}\text { Cryptorchid } \\
\text { castration }\end{array}$ & 2 mins. & 17 minis. \\
\hline
\end{tabular}




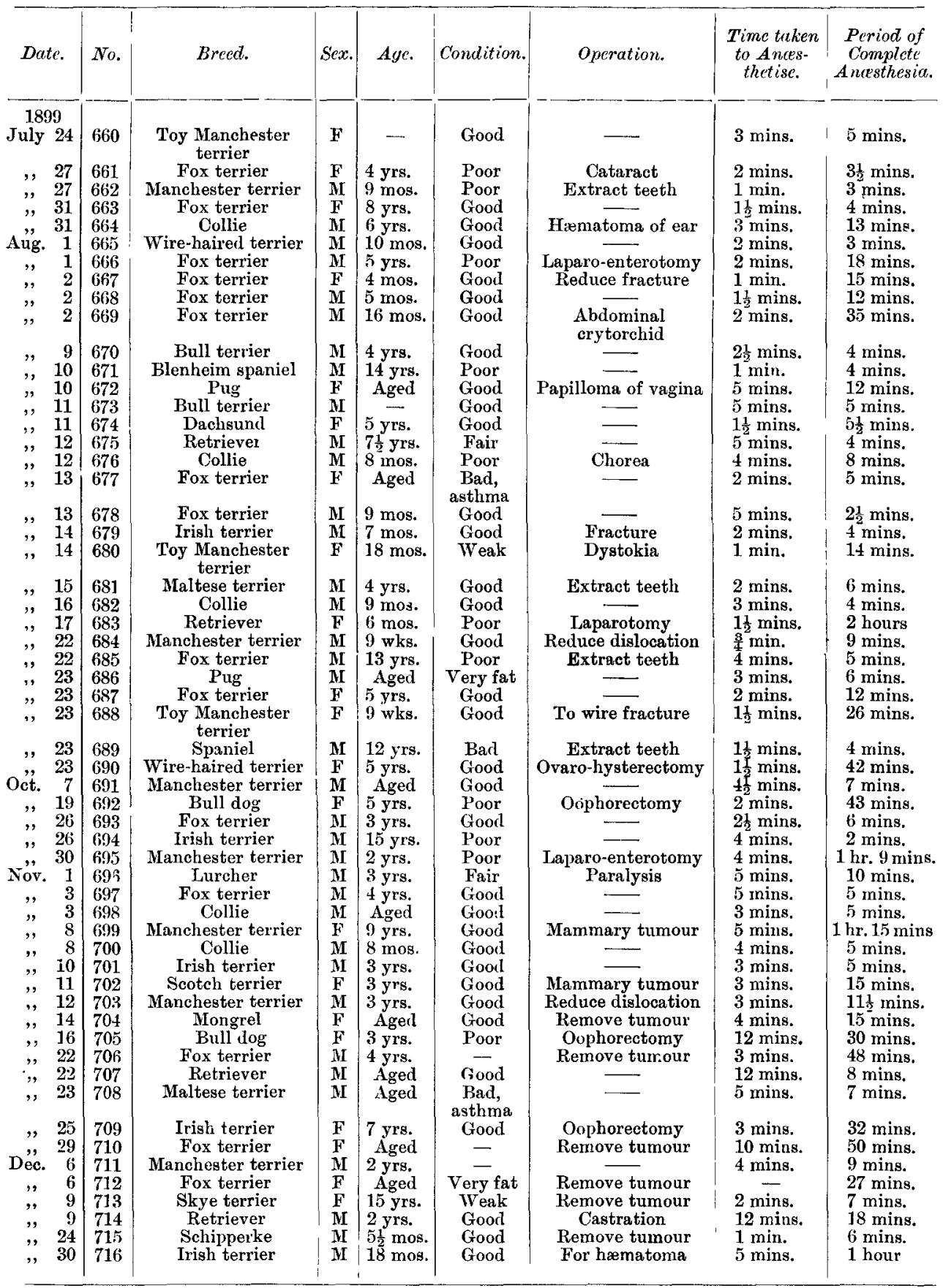


For the notes of the following cases, which were consecutive and not in any way chosen, I am indebted to Messrs W. Anderson and S. M. Woodward, M.R.C.V.S., and Mr John Hobday, a Class C student, who anæsthetised the patients during I 898 and I 899.

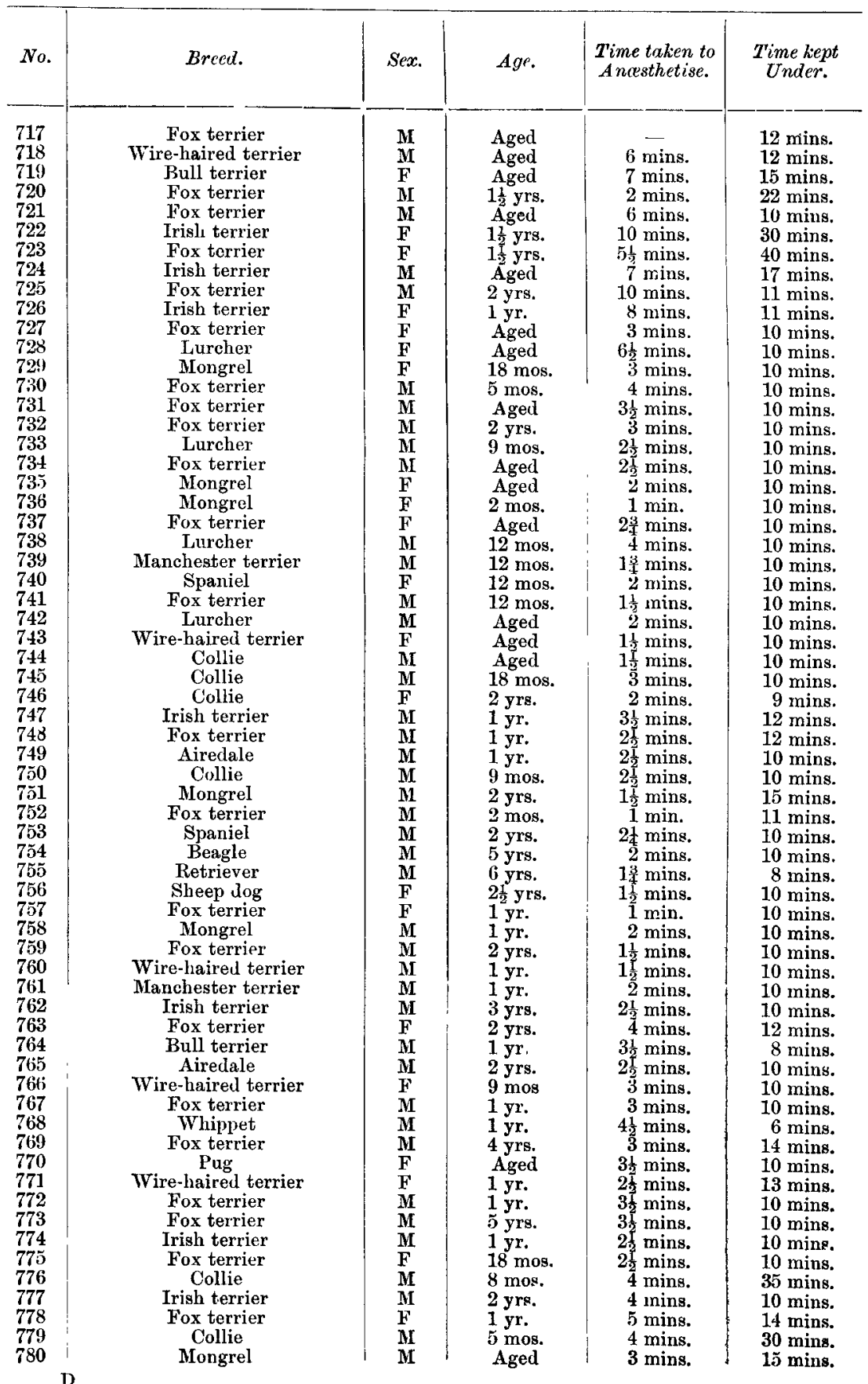




\begin{tabular}{|c|c|c|c|c|c|}
\hline No. & Brecd. & Sex. & Age. & $\begin{array}{c}\text { Time taken to } \\
\text { Ancesthetisr. }\end{array}$ & $\begin{array}{c}\text { Time kept } \\
\text { Under. }\end{array}$ \\
\hline $\begin{array}{l}781 \\
782 \\
783 \\
784 \\
785 \\
786 \\
787 \\
788 \\
789 \\
790 \\
791 \\
792 \\
793 \\
794 \\
795 \\
796 \\
797 \\
798 \\
799 \\
800\end{array}$ & $\begin{array}{c}\text { Welsh terrier } \\
\text { Scotch terrier } \\
\text { Yorkshire terrier } \\
\text { Fox terrier } \\
\text { Manchester terrier } \\
\text { Wire-haired terrier } \\
\text { Fox terrier } \\
\text { Mongrel } \\
\text { Fox terrier } \\
\text { Mongrel } \\
\text { Fox terrier } \\
\text { Beagle } \\
\text { Manchester terrier } \\
\text { Bull } \\
\text { Toy Manchester } \\
\text { Mongrel } \\
\text { Mongrel } \\
\text { Fox terrier } \\
\text { Fox terrier } \\
\text { Pug }\end{array}$ & $\begin{array}{l}\mathbf{M} \\
\mathbf{F} \\
\mathbf{M} \\
\mathbf{M} \\
\mathbf{M} \\
\mathbf{M} \\
\mathbf{F} \\
\mathbf{M} \\
\mathbf{M} \\
\mathbf{F} \\
\mathbf{F} \\
\mathbf{M} \\
\mathbf{M} \\
\mathbf{F} \\
\mathbf{M} \\
\mathbf{M} \\
\mathbf{F} \\
- \\
-\end{array}$ & $\begin{array}{l}1 \text { yr. } \\
\text { Aged } \\
\text { Aged } \\
1 \text { yr. } \\
2 \text { yrs. } \\
\text { Aged } \\
2 \text { yrs. } \\
\text { Aged } \\
\text { Aged } \\
1 \text { yr. } \\
2 \text { yrs. } \\
\text { Aged } \\
1 \text { yr. } \\
\text {-- } \\
1 \text { yr. } \\
\overline{\text { Aged }} \\
5 \text { yrs. } \\
6 \text { mos. }\end{array}$ & $\begin{array}{l}3 \text { mins. } \\
3 \text { mins. } \\
4 \text { mins. } \\
3 \text { mins. } \\
2 \text { mins. } \\
3 \text { mins. } \\
5 \text { mins. } \\
3 \text { mins. } \\
3 \text { mins. } \\
4 \text { mins. } \\
3 \text { mins. } \\
3 \text { mins. } \\
23 \text { mins. } \\
5 \text { mins. } \\
3 \text { mins. } \\
4 \text { mins. } \\
4 \text { mins. } \\
5 \text { mins. } \\
4 \text { mins. } \\
21 \text { mins. }\end{array}$ & $\begin{array}{l}10 \text { mins. } \\
10 \text { mins. } \\
20 \text { mins. } \\
8 \text { mins. } \\
10 \text { mins. } \\
15 \text { mins. } \\
10 \text { mins. } \\
10 \text { mins. } \\
15 \text { mins. } \\
10 \text { mins. } \\
10 \text { mins. } \\
15 \text { mins. } \\
15 \text { mins. } \\
20 \text { mins. } \\
6 \text { mins. } \\
4 \text { mins. } \\
12 \text { mins. } \\
5 \text { mins. } \\
10 \text { mins. } \\
14 \text { mins. }\end{array}$ \\
\hline
\end{tabular}

Out of the 300 cases recorded here two deaths occurred.

CASE 504.- A fat pug, suffering from ulcerating tumours of the vagina. Oöphorectomy was performed and, unfortunately, the tumours were removed and the vagina curetted at the same time. One minute after the chloroform had been taken away the respirations suddenly ceased. Artificial respiration was applied, a full medicinal dose of Scheele's hydrocyanic acid given on the back of the tongue, and ammonia vapour applied to the nostrils. Breathing re-commenced but eventually ceased again, and death took place. I think that death in this case was probably due to shock, as it was a very severe test to perform the two operations at the same time.

In CASF. 549 the animal was observed beforehand to be in very bad condition, and respirations suddenly ceased after anæsthesia had been maintained for five minutes, the heart distinctly beating for fifteen seconds later. Antidotes were not placed ready for use, but artificial respiration was attempted, although without success. Post-mortem examination, made by Professor $\mathrm{M}^{\top}$ Fadyean, revealed well-marked tuberculous lesions in the heart, lungs, diaphragm, liver, bronchial glands, and mesentery. The growths on the pericardium had caused adhesions to form between the latter and the heart itself.

In seven other cases it was found necessary to resort to antidotal measures.

In CASE 527, a Dalmatian upon which laparotomy was being performed, the breathing suddenly ceased after the animal had been under sixteen minutes. The mask was removed as soon as this was observed, but exactly one minute had elapsed before antidotal treatment had really commenced. Artificial respiration was applied, a full medicinal dose of Scheele's hydrocyanic acid was put on the tongue, and ammonia vapour applied to the nostrils. There were no signs of returning life for four minutes, when breathing again commenced, and five minutes after this was quite normal; recovery was permanent. 
In CASE 588, a collie, weak and out of condition, respiration ceased within half a minute after anæsthesia had taken place. Artificial respiration was at once applied, the mask being removed and ammonia vapour held to the nostrils. Respiration recommenced two and a half minutes later, and the animal made a good recovery.

In CASE 59I, a fox terrier puppy, whilst anasthetised for close examination of a damaged pelvis by the Röentgen rays, suddenly ceased breathing, due partly to the fact that the anæsthetist gave the anæsthetic too vigorously when the patient was under, and partly to the fact of the place where the animal was put being very hot and much confined. The patient was moved into the fresh air, hydrocyanic acid was administered as quickly as possible on the tongue, and ammonia vapour held to the nostrils, artificial respiration being practised at the same time. After a lapse of two minutes breathing recommenced, and the dog made a good recovery.

In CASE 597 the patient was also a pup, and owing to the proper apparatus being away an improvised one of the same pattern, which did not work as well as it ought to have done, was used. After being under chloroform for two minutes respirations suddenly ceased; one minim of Scheele's hydrocyanic acid was placed on the tongue, ammonia vapour applied to the nostrils, and artificial respiration applied. Recovery soon took place, and the operation was completed under ether.

In CASE 638 the respiration ceased after the animal had been anæsthetised for one minute. Two minims of Scheele's hydrocyanic acid were placed on the tongue about thirty seconds later and artificial respiration applied. Fully three minutes elapsed before breathing recommenced, but the patient made a good recovery.

In CASE 688 the patient was a toy Manchester terrier puppy. Respiration suddenly ceased after twenty-six minutes of anæsthesia. The administration of one minim of Scheele's hydrocyanic acid, ammonia to the nostrils, and artificial respiration, soon brought about a satisfactory recovery; the breathing recommenced in fortyfive seconds.

In CASE 689 the patient was very old and in bad condition. Respiration ceased suddenly just as complete anæsthesia took place. 'Two minims of Scheele's hydrocyanic acid on the tongue, ammonia vapour to the nostrils, and artificial respiration soon brought about restoration and recovery.

In only one instance (Case 705 ) did vomiting occur.

In CASES 569, 595, 6I9,643,646, and 7 I 4 the action of the apparatus was aided by the careful use of a little chloroform sprinkled on wadding and placed in the end of the mask.

The Cases here recorded are not in any way selected, but run consecutively as occasion arose for the anæesthetisation of the patients. The students were the anæsthetists, and most of them had never seen a dog chloroformed before entering the College. Methylated chloroform was administered, and any that was left was returned into the bottle to be used over again. I think that, when these things are taken into consideration, death in only three instances (all but one fully explained on post-mortem examination) and signs of danger 
shown in only nine other cases, is not an excessive number. Had the patients been selected and prepared, and anæsthetised with the purest chloroform administered by skilled anæesthetists, the percentage of fatalities must have been much smaller still.

For general supervision of the students whilst anæsthetising and operating upon the above patients, and for assistance in collecting the records, I must acknowledge my indebtedness to Messrs Woodruff, Peacey, Wooldridge, and Rix, College Tutors.

\title{
REMARKS ON THE OPERATION OF CASTRATION.
}

\author{
By E. Wallis Hoare, F.R.C.V.S., Cork.
}

I $\mathrm{BEG}$ to offer the following remarks on the above subject, having read with interest the article by $\mathrm{Mr}$ Reeks in the Journal of Comparative Pathology and Therapeutics for December.

There are many methods of performing operations of various kinds, and before we can assert in a dogmatic manner that one method is safer, more surgical, and more convenient than another, we must be prepared to prove our statements in a logical way.

There appears to be a great mystery in connection with the operation of castration, if we draw conclusions from the writings on the subject by so-called experts. But practical experience teaches us that in uncomplicated cases it is one of the simplest and safest operations the veterinary surgeon is called upon to perform. Attention to antiseptic precautions, and a proper method of preventing hæmorrhage are the most important details in connection therewith.

I must confess that I fail to see how $\mathrm{Mr}$ Reeks arrives at the first of his conclusions, viz., "that of the only two really safe methods, the clam and hot iron is eventually the most convenient."

This conclusion -is somewhat peculiar, when we read further back that on purely theoretical grounds he has not given the operation by torsion a fair trial.

This method, I contend, is a far more surgical method of performing the operation than either of those he mentions; and as to its safety I can vouch from practical experience. Surely torsion of an artery is more in accordance with modern ideas of surgery than the use of the actual cautery for the suppression and prevention of hæmorrhage; because the latter must of necessity injure a certain amount of tissue.

In the operation by torsion we do not, as stated by Mr Reeks, "simply grasp the whole of the cord in one pair of clams and twist it off in its entirety with a second." We sever the non-vascular portion of the cord above the epididymis by means of serrated scissors, and then apply a properly constructed clamp to the vascular portion. The torsion forceps are then applied as close as possible to the surface of the clamp, and the vascular portion of the cord is twisted off.

It would be bad surgery to place the entire cord in the clamp, as the effect would be to bruise an unnecessary amount of tissue and cause a slough. The aim in the operation should be to bruise as little tissue as possible, and with the aid of a properly constructed clamp this amount is reduced to a minimum. 